Obecnie lekami powszechnie stosowanymi w terapii raka piersi są taksany. W wielu przypadkach po ich podaniu rozwija się jednak oporność wielolekowa, która obniża skuteczność chemioterapii. Taksany powodują także liczne skutki uboczne, takie jak neutropenia czy neuropatia. Epotilony są nową grupą związków o mechanizmach działania zbliżonych do taksanów, ale znacznie silniejszym działaniu antyproliferacyjnym. W niniejszym artykule przedstawiono budowę chemiczną oraz mechanizmy działania epotilonów. Scharakteryzowano także kilka wybranych związków z tej grupy, dla których prowadzone są intensywne badania i z którymi wiąże się największe nadzieje w terapii nowotworów. Wśród nich znalazły się: patupilon (epotilon B), iksabepilon (BMS-247550), sagopilon (ZK-EPO) czy KOS-862 (epotilon D). Wykazano ponadto, że epotilony są skuteczne także w komórkach opornych na taksany. Wydaje się, że jest to grupa związków, która w najbliższej przyszłości może zastąpić taksany w terapii różnego typu nowotworów.

Słowa kluczowe: epotilony, taksany, antracykliny, mikrotubule, mechanizmy działania.

\section{Epotilony - nadzieja dla pacjentów niewrażliwych na leczenie taksanami}

\author{
Epothilones - hope for patients not susceptible to treatment \\ with taxanes
}

\author{
Aneta Rogalska, Agnieszka Marczak, Marzena Szwed, Arkadiusz Gajek, \\ Zofia Jóźwiak
}

Katedra Termobiologii, Instytut Biofizyki, Uniwersytet Łódzki

\section{Wstęp}

Epotilony odkryto w 1987 r. w Afryce (Zambesi River) podczas fermentacji bakterii glebowych. Zostały one wyizolowane z miksobakterii Sorangium cellulosum i zakwalifikowane do grupy związków o aktywności przeciwgrzybiczej [1]. Okazały się jednak zbyt toksyczne, by mogły być wykorzystane jako środek przeciwgrzybiczy, ale znalazły zastosowanie w terapii przeciwnowotworowej. Podobnie jak stosowane od kilkunastu już lat w terapii raka piersi taksany (paklitaksel i docetaksel), epotilony indukują agregację tubuliny i powodują zatrzymanie mitozy oraz zapobiegają depolimeryzacji mikrotubul [2]. Epotilony mają jednak znaczącą przewagę nad taksanami. Są skuteczne także w komórkach opornych na taksany i mogą zastapić je w terapii przeciwnowotworowej.

\section{Budowa chemiczna i charakterystyka wybranych epotilonów}

Epotilony zbudowane są z 16-członowego pierścienia [3]. Czas połowicznego rozpadu epotilonów, zależnie od ich struktury, waha się od 7 do 89 godz. Metabolizowane są głównie w wątrobie i wydalane w 52\% w kale i 25\% w moczu [4]. Jednym z pierwszych odkrytych epotilonów był epotilon B (Epo B), który w 92\% wiąże się z białkami błony plazmatycznej, podczas gdy inny z epotilonów, iksabepilon - w 79,4\%. Niemniej jednak interakcja epotilonów z błoną plazmatyczną nie wpływa na siłę wiązania się do tubuliny [5]. Epotilon A (Epo A) i Epo B (ryc. 1.) są jedynymi z tej grupy związków lekami pochodzenia naturalnego. Zasadnicza różnica między nimi polega na tym, że Epo B ma dodatkową grupę metylową w pozycji C12. Silniej stabilizuje on mikrotubule. Epotilony A i B znajdują się obecnie w III fazie badań klinicznych [2]. Kolejne analogi epotilonów powstawały głównie w wyniku modyfikacji epoksydu w pozycjach C12-13. Wynikiem tych zmian są epotilony E i F (Epo E, Epo F), odznaczające się większym powinowactwem do mikrotubul. Epotilony mogą mieć również strukturę olefin, czyli związków chemicznych z grupy węglowodorów nienasyconych, w których występuje jedno lub więcej podwójnych wiązań między atomami węgla. Przykładem tego typu połączeń są epotilony C i D (Epo C, Epo D) [6].

Na rycinie 1. i w tabeli 1. przedstawiono strukturę oraz ogólną charakterystykę kilku wybranych epotilonów, nad którymi prowadzone są intensywne badania i z którymi wiąże się największe nadzieje, że znajdą powszechne zastosowanie w terapii nowotworów.

Dotąd jedynym epotilonem, który został zarejestrowany w Stanach Zjednoczonych (2007 r.), jest iksabepilon (BMS-247550). W Polsce nie zostat on dotychczas wprowadzony, z uwagi na duże ryzyko rozwoju neuropatii. Związek ten jest pochodną drugiej generacji epotilonów, w którym w miejsce tlenu w pozycji 16. pierścienia makrolidowego podstawiona została grupa azy- 
Nowadays commonly used drugs in the treatment of breast cancer are the taxanes. However, in many cases after their administration, there develops multidrug resistance which reduces the effectiveness of chemotherapy. Taxanes also cause numerous side effects such as neutropenia and neuropathy. Epothilones are a new group of compounds with mechanisms of action similar to taxanes, but with more potent antiproliferative activity. This review presents the chemical structure of epothilones and their mechanism of action. We also characterise several compounds that belong to epothilones: patupilone (epothilone B), ixabepilone (BMS-247550), sagopilone (ZK-EPO) and KOS-862 (epothilone D). There has been carried out extensive research on them. The main advantage of epothilones is their efficacy in cells resistant to taxanes. It seems that this is a group of compounds which in the near future may replace the taxanes in the treatment of various types of cancer.

Key words: epothilones, taxanes, anthracyclines, microtubules, mechanisms of action. nowa (ryc. 1.). Dzięki temu jest on bardziej oporny na degradację przez karboksyesterazy [2]. W porównaniu z naturalnymi związkami jest lepiej rozpuszczalny w wodzie [7]. Iksabepilon jest metabolizowany do ok. 30 nieaktywnych metabolitów [8]. W jego metabolizmie udział biorą cytochromy CYP3A4 i CYP3A5. Stwierdzono, że zastosowanie ketokonazolu, inhibitora tych cytochromów, zwiększa stężenie leku w organizmie [9]. Może być podawany doustnie i pomimo wysokiego poziomu ekspresji glikoproteiny P (glycoprotein P-P-gp) w komórkach jelita, ulega wchłanianiu i zachowuje wysoki poziom aktywności [10]. Prowadzone są także badania aktywności przeciwnowotworowej iksabepilonu podawanego w skojarzeniu z innymi lekami. Sprawdzano m.in. skuteczność podawania iksabepilonu z karboplatyną i trastuzumabem w leczeniu dającego przerzuty raka piersi z ekspresją HER2. Gen dla receptora typu 2 ludzkiego naskórkowego czynnika wzrostu (HER2, HER2/neu, c-erbB-2) jest protoonkogenem zlokalizowanym na chromosomie 17q21. Częściowa odpowiedź była obserwowana u 40\% pacjentek, a całkowita u 2 na 59 badanych kobiet [11]. Badania nad terapią iksabepilonem i trastuzumabem wchodzą w III fazę badań klinicznych, w tym także u pacjentek uprzednio leczonych taksanami. Iksabepilon okazał się również skuteczny w leczeniu chorych z potrójnie ujemnym fenotypem raka piersi (estrogen receptor-, progesterone receptor-, and human epidermal growth factor 2-negative - ER-PR-HER-2) [12]. Lek był również badany w połączeniu z kapecytabiną, która jest karbaminianem fluoropirymidyny, będącym prekursorem 5-fluorouracylu (5-FU) [13]. Badaniom poddano 752 osoby z przerzutowym rakiem piersi, oporne na leczenie taksanami i antracyklinami. Iksabepilon podawano w dawce $40 \mathrm{mg} / \mathrm{m}^{2}$, a kapecytabinę w stężeniu $2 \mathrm{mg} / \mathrm{m}^{2}$. Obydwa leki podawane jednocześnie zwiększały przeżywalność u 35\% pacjentów o ok. 6 miesięcy. Do skutków ubocznych terapii można zaliczyć: erytrodyzestezję dłoniowo-podeszwową, bóle mięśniowe, biegunkę, astenię, łysienie (mniej nasilony proces niż po leczeniu taksanami) i uszkodzenie wątroby [7]. Jednym z poważniejszych działań niepożądanych epotilonów jest także neuropatia, która wystąpiła u 65\% pacjentów. Badania potwierdzają jednak, że neuropatia indukowana przez iksabepilon jest znacznie łatwiej odwracalna niż pojawiająca się po podaniu paklitakselu [14]. Iksabepilon może być stosowany z kapecytabiną u chorych opornych na działanie taksanów czy antracyklin lub u pacjentów, którzy jednocześnie z epotilonem dostają antracykliny. Monoterapia iksabepilonem jest stosowana w dającym przerzuty i lokalnie zaawansowanym raku piersi u pacjentów opornych na taksany, antracykliny i kapecytabinę. Iksabepilon stosowano również w leczeniu niedrobnokomórkowego raka płuc (non-small cell lung cancer- NSCLC). W badaniach tych stosowano iksabepilon w połączeniu z karboplatyną i porównywano z próbami, w których z karboplatyną podawany był paklitaksel. Próby kliniczne były obiecujące, zwłaszcza u pacjentów z nadekspresją izoform $\beta$ III tubuliny [15].

Interesującą pochodną jest także dezoksyepotilon (KOS-862, epotilon D), w strukturze którego nie ma ugrupowania epoksydowego w pozycji C12-13 (ryc. 1.). Związek ten wykazuje aktywność równą taksanom, będąc przy tym mniej toksyczny dla pacjenta nawet w porównaniu z epotilonem B, co świadczy o tym, że pierścień epoksydowy nie jest konieczny do uzyskania efektu terapeutycznego [2]. Epotilon D jest stosowany w leczeniu raka piersi, jajników, jąder i trzustki. W fazie I/II badań znajduje się terapia polegająca na jednoczesnym podawaniu Epo D i trastuzumabu u pacjentów z guzami wykazującymi ekspresję receptorów HER-2. Leczeniu poddano 13 pacjentek z rakiem piersi dającym przerzuty. Nie ma określonej dawki powodującej skutki uboczne leku, natomiast istotny wpływ na efekt neurotoksyczny ma jego kumulacja. U 11 pacjentek zaobserwowano parestezję (głównie II stopnia), u połowy z nich bóle neuropatyczne, a oprócz tego zawroty głowy, zaburzenia smakowe, ataksję i bezsenność. W II fazie badań klinicznych 29 pacjentkom, uprzednio leczonym taksanami i antracyklinami, podawano lek w dawce $100 \mathrm{mg} / \mathrm{m}^{2}$. Zaobserwowano u 5 z nich częściową poprawę i tylko niewielkie 


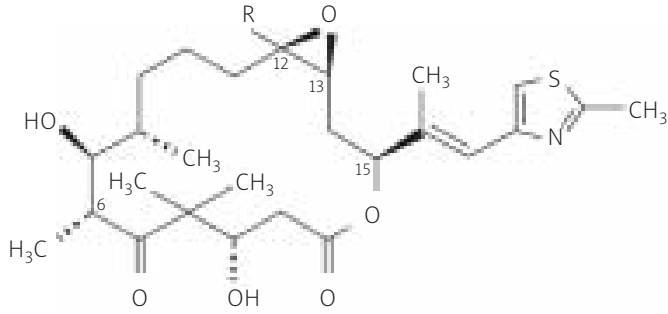

epotilon $A(E p o A): R=H$ epotilon $B(E p o B): R=\mathrm{CH}_{3}$<smiles>C/C(=C/C[C@@H](OC(=O)C[C@@H](O)C(C)(C)C(=O)[C@H](C)[C@@H](O)[C@@H](C)CCC/C(C)=C/c1csc(C)n1)/C(C)=C/c1csc(C)n1)CCC(C)C</smiles>

epotilon D<smiles>C/C(=C\c1csc(C)n1)[C@H](C[C@@H]1O[C@]1(C)CCC[C@@H](C)[C@H](O)[C@@H](C)C(=O)C(C)(C)[C@H](O)CC(=O)N[C@@H]1O[C@@H]1C)C(C)(C)C</smiles>

iksabepilon (Ixempra ${ }^{\mathrm{TM}} ;$ BMS-247550)<smiles>C=CC[C@@H](C(=O)C(C)(C)[C@@H](O)CC(=O)O[C@H](C[C@@H]1O[C@]1(C)CCC[C@H](C)[C@H](O)C(C)C)c1ccc2sc(C)nc2c1)C(C)(C)C</smiles>

sagopilon (ZK-EPO)

Ryc. 1. Chemiczna struktura wybranych epotilonów (na podstawie [2] zmodyfikowany)

Fig. 1. Chemical structure of epothilones (based on [2] modified)

działanie neurotoksyczne. Epotilon D podawany jest także pacjentom z rakiem jelita grubego i niedrobnokomórkowym rakiem płuc w połączeniu z karboplatyną. Obecnie badania są w II fazie prób klinicznych [15].

Przykładem leku III generacji jest sagopilon (ZK-EPO, ZK-219447), który jest syntetycznym epotilonem zaprojektowanym w celu zapobieżenia oporności wielolekowej (multi-drug resistance - MDR). Jest on rozpuszczalny w wodzie, efektywniej i szybciej niż inne epotilony lokuje się w komórce. W I fazie badań klinicznych stosowano go w dawce 0,6-29 mg/m², w 30-minutowym wlewie dożylnym u 47 pacjentów z guzami litymi [16]. W linii A549 niedrobnokomórkowego raka płuc (non small cell lung cancer) lek lokował się w cytoplazmie i przyspieszał polimeryzację tubuliny w większym stopniu niż taksany [17]. Lek ten znaj- duje się obecnie w II fazie badań klinicznych. Stosowany jest m.in. u chorych na raka mózgu, niedrobnokomórkowego raka płuc, raka piersi i czerniaka [18].

\section{Mechanizmy działania epotilonów}

Główny mechanizm działania epotilonów polega na ich oddziaływaniach z tubuliną, globularnym białkiem tworzącym protofilamenty mikrotubul. Mikrotubule odgrywają istotną rolę w utrzymywaniu kształtu komórek, podziałach komórkowych, rozmieszczeniu i ruchu organelli komórkowych, a także pęcherzyków cytozolowych i białek. Prawidłowe funkcjonowanie tych białkowych polimerów wymaga ciągłych procesów polimeryzacji i depolimeryzacji, przebiegających na końcach filamentów. Wiązanie się epotilonów do tubuliny powoduje zahamowanie depolimery-

Tabela 1. Epotilony stosowane w badaniach klinicznych (na podstawie [2] zmodyfikowany) Table 1. Epothilones used in clinical trials (based on [2] modified)

\begin{tabular}{lccc} 
Związek & Pochodzenie & Rozpuszczalnik stosowany klinicznie & Skutki uboczne terapii \\
\hline patupilon & naturalne & polietylenoglikol 300 & biegunka \\
\hline BMS-310705 & II generacji Epo B & woda & hematologiczne/hiponatremia \\
\hline iksabepilon & II generacji Epo B & kremofor EL & hematologiczne/neurologiczne \\
\hline sagopilon & III generacji Epo & woda & neurologiczne \\
\hline epotilony D & brak epoksydu w pozycji & kremofor EL & neurologiczne \\
& C12-13 Epo B & & hepatotoksyczność/biegunka \\
\hline KOS-1584 & II generacji Epo D & woda & \\
\hline
\end{tabular}


zacji mikrotubul i w konsekwencji zaburzenia procesów, w które zaangażowane są te polimery. Epotilon B poprzez wpływ na wrzeciono mitotyczne, prowadzi do zatrzymania cyklu komórkowego w fazie G2/M i apoptozy [5]. Epotilony B i D (1-1000 nmol/l) prowadziły w linii komórkowej raka jelita, SW620, do zatrzymania cyklu komórkowego w fazie G2/M (Epo B - po 12 godz., Epo D - po 36 godz.), polimeryzacji tubuliny, a także aktywacji czynnika transkrypcyjnego

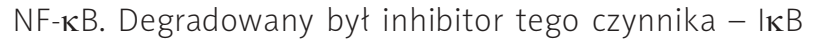
w wyniku aktywacji kinaz (IKK $\alpha$ i IKK $\beta$ ), co prowadziło do translokacji białka p50 i p65 do jądra. W komórkach traktowanych Epo B i Epo D obserwowano powstawanie dimerów białka p50 i $\beta$-tubuliny [19].

Epotilony indukują również apoptozę w stężeniach, które nie powodowały zatrzymania cyklu komórkowego [20]. Badania z wykorzystaniem iksabepilonu pozwolity stwierdzić, że uruchamia on kilka różnych szlaków apoptotycznych. Prowadzi do zwiększenia aktywności kaspazy 2 i 3. Obserwowano także wzrost ekspresji białka Bax i PUMA [21]. Epotilony powodują zwiększoną ekspresję zależnych od czynnika NF-kB, związanych z apoptozą genów bax, p53 czy kaspazy 3 [19]. Białko p53 może indukować apoptozę w sposób niezależny od transkrypcji genów, co może być związane z udziałem białka Bax w odpowiedzi na działanie iksabepilonu [22]. Griffin i wsp. [23] stwierdzili, że iksabepiIon prowadzi do uwalniania cytochromu c z mitochondriów oraz aktywuje białko Smac/DIABLO (second mitochondriaderived activator of caspase), które jest antagonistą inhibitora apoptozy, białka IAP (inhibitor of apoptosis proteins). Sagopilon nie indukuje wzrostu ekspresji glikoproteiny P, więc pozostaje w komórce dłużej niż inne epotilony. Podobnie jak iksabepilon, uruchamia on wewnętrzny szlak apoptotyczny i aktywuje kaspazę 3 [16]. Z kolei w komórkach neuroblastomy Epo B powoduje obniżenie potencjału błony mitochondrialnej, zmiany morfologiczne w mitochondriach oraz uwalnianie cytochromu c, co prowadzi do apoptozy. Po 2-godzinnej inkubacji z lekiem odnotowano zwiększone stężenie reaktywnych form tlenu (RFT), głównie nadtlenków (33\%) oraz nadtlenku wodoru (51\%). Po 6 godz. inkubacji z patupilonem obserwowano translokację białka Bim do mitochondriów [24].

Skuteczność leczenia w dużym stopniu zależy też od zdolności stosowanych leków do hamowania angiogenezy. Komórki nowotworowe zapewniają sobie zaopatrzenie w niezbędne do rozwoju i ekspansji substancje odżywcze i tlen poprzez tworzenie sieci nowych naczyń krwionośnych [25]. Wprowadzenie do terapii antynowotworowej związków, które hamowałyby ten proces, wydaje się wysoce obiecującym kierunkiem, uzupełniającym leczenie chirurgiczne czy chemioterapię. Stwierdzono, że epotilony mają właściwości antyangiogenne [2]. W przypadku Epo B są one związane z zaburzeniem ekspresji czynnika indukowanego hipoksją $1 \alpha$ (hypoxia inducible factor $1 \alpha-\mathrm{HIF}-1 \alpha$ ). Badania prowadzone na komórkach śródbłonka pozyskanych z żyły pępowinowej (human umbilican vein endothelial cells HUVEC), które traktowano epotilonem B (1 nM/L, godzinna inkubacja), wykazały zahamowanie inwazyjności i migracji tych komórek. Związek ten zapobiegał aktywacji białek Rac1 i Cdc42, indukując zaburzenia w strukturze włókien aktyny i tworzenie pierścieni wokół jądra komórek śródbłonka. Białko Rac1 powoduje powstawanie lamellipodiów i stymuluje polimeryzację aktyny na przedniej krawędzi komórki, co skutkuje pojawieniem się nowych miejsc przyczepności do macierzy. Z kolei GTP-azy Rho należą do nadrodziny białek koordynujących ruchliwość komórek. Białko Cdc42 reguluje polarność komórek, umożliwiając ruch komórek w żądanym kierunku. Od białek Cdc42 zależy również orientacja centromeru. Zaobserwowano, że w małych, subtoksycznych stężeniach epotilony, wpływając na integralność cytoszkieletu, przyczyniają się do zahamowania procesu angiogenezy [26].

Epotilony to związki neurotoksyczne, co pozwala stosować je w leczeniu raka mózgu oraz w nowotworach dających przerzuty do mózgu. Ponieważ rak piersi przerzutuje do mózgu, wykorzystanie epotilonów w jego terapii ma dodatkowe zalety. Neurotoksyczność tych związków zależy od kilku czynników, w tym od zdolności do przekraczania bariery krew-mózg i krew-nerw. Badania nad poznaniem mechanizmu prowadzącego do neurotoksyczności i jej zapobieganiu prowadzili Chiorazzi i wsp. [27] na dwóch szczepach szczurów: Wistar i Fisher. Wykazały one zarówno różnice we wrażliwości na Epo B, jak i różnice w poziomie neurotoksyczności. W obu szczepach dochodzi do hiperpolimeryzacji tubuliny w aksonach, czego wynikiem jest aksonopatia. Poziom mRNA białek mielinowych również ulegał zmianie. Wykazano ponadto, że Epo B indukuje śmierć komórkową w przypadku glejaka wielopostaciowego poprzez regulację stężenia surwiwiny. Lek wywierał silny efekt cytotoksyczny zarówno w komórkach z prawidłową ekspresją białka p53, jak i w komórkach glejaka z brakiem ekspresji tego białka. Ponadto, dochodziło także do redukcji filamentów $\alpha$-tubuliny. Obserwowano również indukowaną lekiem apoptozę w postaci fragmentacji chromatyny i ciałek apoptotycznych [28].

\section{Epotilony a taksany}

Spośród licznych leków przeciwnowotworowych badanych w ostatnich dwóch dekadach kilka znalazło zastosowanie w badaniach przedklinicznych i klinicznych jako związki stabilizujące mikrotubule. Wśród nich są: paklitaksel i docetaksel. Jako pierwszy został odkryty paklitaksel, którego mechanizm działania opiera się na interakcji z podjednostkami tubuliny i w efekcie na zaburzeniach procesu formowania jej polimerów. Związki te wyizolowano z kory i igieł cisu. Stosowane są głównie w leczeniu raka piersi i jajnika [29].

Badania biologiczne wykazały, że epotilony stabilizują mikrotubule na tej samej drodze, co paklitaksel, ale z nieco większą wydajnością. Epotilony wiążą się również z tym samym miejscem na polimerze tubuliny $\beta$ co paklitaksel. Dzielą jedno polarne miejsce w pozycji C7-OH, podczas gdy boczny łańcuch tiazolowy wiąże się z innym regionem $\beta$-tubuliny niż taksany. Siła działania epotilonów jest 2-10 razy większa niż taksanów [6]. Ponadto epotilony są kompetycyjnymi inhibitorami taksanów. Hamują ich wiązanie się do spolimeryzowanej postaci tubuliny, co świadczy o tym, że obie grupy leków współzawodniczą o miejsce wiązania na tubulinie [3]. 
W porównaniu z taksanami epotilony lepiej rozpuszczają się w wodzie, a szkielet cząsteczki jest łatwiejszy do modyfikacji chemicznej [3].

Porównawcze badania prowadzone na pierwotnych i wtórnych guzach mózgu u myszy wykazały, że epotilony przekraczają barierę krew-mózg. Sagopilon wykazywał znaczące właściwości przeciwnowotworowe zarówno w modelu U373, jak i U87 ludzkiego glejaka, podczas gdy paklitaksel miał nieznaczny wpływ na te komórki. Sagopilon, w przeciwieństwie do paklitakselu, znacząco hamował tak że wzrost guzów dających przerzuty (MDA-MB-435 melanoma, patient-derived Lu7187 i Lu7466 NSCLC) wszczepionych myszom [18].

Jedną z przyczyn niepowodzeń chemioterapii jest nabywanie przez komórki oporności na stosowane leki. Wzrost ekspresji genu MDR-1 zlokalizowanego na długim ramieniu chromosomu 7 związany jest z powstawaniem P-gp, białka o ciężarze właściwym 170 kDa, które jest odpowiedzialne za występowanie zjawiska oporności wielolekowej, w tym również na taksany [30]. Badania wykazały, że epotilony, w przeciwieństwie do taksanów, są skuteczne także w komórkach z nadekspresją P-gp czy białka związanego z opornością wielolekową (multidrug resistance - associated protein - MRP-1). Stwierdzono, że epotilony indukowaty proces apoptozy w stransfekowanych komórkach raka płuc, niewrażliwych na paklitaksel [31]. Iksabepilon był kilkaset razy bardziej aktywny niż taksany w linii raka wątroby - SNU-449 z silną ekspresją P-gp [10]. Ponadto hodowla komórek raka jajnika linii A2780 prowadzona przez 3 lata w obecności iksabepilonu nie wywołała oporności w tych komórkach, w przeciwieństwie do paklitakselu, gdzie oporność pojawiła się już po 6 miesiącach [32, 33]. Epotilon B hamuje wzrost komórek z nadekspresją P-gp. Jest on 10 do 3000 razy bardziej skuteczny niż paklitaksel w liniach raka piersi wykazujących oporność na paklitaksel [5].

Epotilon B i paklitaksel były również badane w połączeniu z radioterapią $w$ linii gruczolakoraka jelita (colon adenocarcinoma cell line - SW480), która wykazywała nadekspresję P-gp oraz miała zmutowane białko p53. W celu porównania badano także linię genetycznie zmodyfikowanych mysich fibroblastów (pozbawionych genu E1/ras). Oba leki w połączeniu z radioterapia miały efekt cytotoksyczny na linię fibroblastów. Jednakże linia SW480 okazała się być wrażliwa tylko na Epo B $(0,1 \mathrm{mmol} / \mathrm{l})$, stosowany po dawce (2-5 Gy) promieniowania jonizującego. W komórkach tych obserwowano proces apoptozy i zatrzymanie cyklu komórkowego nie w fazie G2/M, lecz w fazie S. Małe stężenie Epo B, jakie zastosowano w tych badaniach, mogło prowadzić do zaburzeń mitozy, powstawania komórek aneuploidalnych powiązanych ze wzrostem ekspresji genów zależnych od stresu i CD95 [34].

Cechą wspólną taksanów i epotilonów jest natomiast możliwość generowania oporności wielolekowej na drodze aktywacji jądrowego receptora PXR (pregnane $X$ receptor) znanego także jako receptor steroidów i ksenobiotyków (steroid and xenobiotic receptor-SXR), który jest jednym z czynników odpowiedzialnych za oporność na leki [35]. Badania prowadzone na linii komórkowej embrionalnych mysich fibroblastów (MEF3.8), niewykazujących ekspresji P-gp i białka
MRP1, a także na linii komórek nerki (HEK 293) dowiodły, że przyczyną oporności zarówno na taksany, jak i Epo B może być białko MRP7 (ABCC10). Praca Hopper-Borge i wsp. [36] wykazała, że również epotilony mogą być usuwane z komórki, co ograniczy ich skuteczność. Aktywność tego transportera w linii MEF3.8 spowodowała wyraźny wzrost oporności na docetaksel (46-krotnie) i paklitaksel (116-krotnie) oraz stosunkowo niski na Epo B (3,3-krotnie). Zwiększonej lekooporności nie obserwowano w przypadku Epo A [36].

Ponadto oporność na taksany rozwija się w wyniku nadekspresji białka $\tau$, którego główną fizjologiczną funkcją jest udział w procesach polimeryzacji tubuliny i stabilizacji mikrotubul czy w wyniku mutacji w strukturze $\beta$-tubuliny [37]. Niemniej jednak nie wykazano oporności krzyżowej między taksanami i epotilonami, co daje możliwość skutecznego stosowania epotilonów u pacjentów niewrażliwych na taksany.

\section{Podsumowanie}

Epotilony należą do związków zaburzających funkcje wrzeciona podziałowego. Te inhibitory depolimeryzacji mikrotubul okazały się skuteczne u pacjentów wykazujących oporność na taksany i antracykliny. Cechują się silnym działaniem antyproliferacyjnym. Są także zdolne indukować apoptotyczną śmierć komórek oraz mają właściwości antyangiogenne. Mają zdecydowaną przewagę nad taksanami, mimo że nie udało się znacząco ograniczyć toksyczności systemowej towarzyszącej tym związkom. Praktycznie zawsze obserwuje się biegunkę, neutropenię i bardziej lub mniej nasilone, w zależności od typu stosowanej pochodnej, neuropatię czy zmęczenie. Niemniej jednak efekty uboczne ustępują szybciej niż te wywołane taksanami po zakończeniu chemioterapii. Skuteczność doustnie podawanych epotilonów była porównywalna z uzyskaną w terapii dożylnej w przypadku raka jajnika czy jelita grubego w przeciwieństwie do taksanów, których form doustnych nie udało się zastosować. Dotychczas epotilony były podawane głównie w leczeniu raka piersi. Obecnie trwają badania kliniczne III fazy w celu poszukiwania wrażliwych na epotilony typów nowotworów. Prowadzone są także badania nad wpływem flawopirydiolu (FP), będącego syntetycznym flawonoidem, który hamuje cykliny w połączeniu z Epo B. Efekt współdziałania tych związków w badaniach prowadzonych na komórkach raka piersi prowadzit do zmniejszenia stężenia białek antyapoptotycznych i zwiększenia efektu terapeutycznego [38]. Testowane są także nowe analogi, takie jak np. C12-C13-oksazolinowe pochodne epotilonu A [39]. Poszukuje się również kolejnych epotilonów pochodzenia naturalnego. Ze szczepu So0157-2 miksobakterii wyizolowano pięć pochodnych 3- $\alpha$-D-arabinofuranozydowych [40]. Dalsze badania kliniczne oraz in vitro pozwolą na lepsze poznanie mechanizmów działania epotilonów i jednoczesne ograniczenie skutków ubocznych chemioterapii.

\section{Piśmiennictwo}

1. Lee JJ, Swain SM. The epothilones: translating from the laboratory to the clinic. Clin Cancer Res 2008; 14: 1618-24.

2. Cheng KL, Bradley T, Budman DR. Novel microtubule-targeting agents - the epothilones. Biologics 2008; 2: 789-811. 
3. Fojo T, Menefee M. Mechanisms of multidrug resistance: the potential role of microtubule-stabilizing agents. Ann Oncol 2007; 18: 3-8.

4. Beumer JH, Garner RC, Cohen MB, Galbraith S, Duncan GF, Griffin $\mathrm{T}$, Beijnen $\mathrm{JH}$, Schellens $\mathrm{JH}$. Human mass balance study of the novel anticancer agent ixabepilone using accelerator mass spectrometry. Invest New Drugs 2007; 25: 327-34

5. Altmann KH, Hüsken D, Cuenoud B, García-Echeverría C. Synthesis and hybridization properties of polyamide based nucleic acid analogues incorporating pyrrolidine-derived nucleoamino acids. Bioorg Med Chem Lett 2000; 10: 929-33.

6. Goodin S. Novel cytotoxic agents: Epothiones. Am J Health-Syst Pharm 2008; 65: 10-15.

7. Thomas ES, Gomez HL, Li RK, Chung HC, Fein LE, Chan VF, Jassem J, Pivot XB, et. al. Ixabepilone plus capecitabine for metastatic bre ast cancer progressing after anthracycline and taxane treatment. J Clin Oncol 2007; 25: 5210-7.

8. Egerton N. Ixabepilone (ixempra), a therapeutic option for locally advanced or metastatic breast cancer. P T 2008; 33: 523-31.

9. Steinberg M. Ixabepilone: a novel microtubule inhibitor for the treatment of locally advanced or metastatic breast cancer. Clin Ther 2008; 30: 1590-617.

10. Mok TS, Choi E, Yau D, Johri A, Yeo W, Chan AT, Wong C. Effects of patupilone (epothilone B; EPO906), a novel chemotherapeutic agent, in hepatocellular carcinoma: an in vitro study. Oncology 2006; 71: 292-6.

11. Moulder SL, Arteaga CL. A Phase I/II Trial of trastuzumab and gefitinib in patients with Metastatic Breast Cancer that overexpresses HER2/neu (ErbB-2). Clin Breast Cancer 2003; 4: 142-5.

12. Gradishar W. Management of advanced breast cancer with the epothilone B analog, ixabepilone. Drug Des Devel Ther 2009; 3: 163-71.

13. Załuska J, Prochowska E, Karczewska-Dzionk A, Załuski J, Wysocki PJ. Kapecytabina w monoterapii u chorych z uogólnionym rakiem piersi - obserwacje własne na tle danych literaturowych. Współcz Onkol 2008; $12: 384-7$

14. Pignata S, De Placido S, Biamonte R, et. al. Residual neurotoxicity in ovarian cancer patients in clinical remission after first-line chemotherapy with carboplatin and paclitaxel: the multicenter italian trial in ovarian cancer (MITO-4) retrospective study. BMC Cancer 2006; 7: 1-7

15. Edelman MJ. Novel taxane formulations and microtubule-binding agents in non-small-cell lung cancer. Clin Lung Cancer 2009; 10: 30-4.

16. Cardoso F, de Azambuja E, Lago LD. Current perspectives of epothilones in breast cancer. Eur J Cancer 2008; 44: 341-52.

17. Hoffmann J, Vitale I, Buchmann B, et. al. Improved cellular pharmacokinetics and pharmacodynamics underlie the wide anticancer activity of sagopilone. Cancer Res 2008; 68: 5301-8.

18. Hoffmann J, Fichtner I, Lemm M, Lienau P, Hess-Stumpp H, Rotgeri A, Hofmann B, Klar U. Sagopilone crosses the blood-brain barrie in vivo to inhibit brain tumor growth and metastases. Neuro Oncol 2009; 11: 158-66.

19. Lee SH, Son SM, Son DJ, et. al. Epothilones induce human colon cancer SW620 cell apoptosis via the tubulin polymerization indepen dent activation of the nuclear factor-kappaB/lkappaB kinase signal pathway. Mol Cancer Ther 2007; 6: 2786-97.

20. Goodin S, Kane MP, Rubin EH. Epothilones: mechanism of action and biologic activity. J Clin Oncol 2004; 22: 2015-25.

21. Yamaguchi H, Chen J, Bhalla K, Wang HG. Regulation of Bax activation and apoptotic response to microtubule-damaging agents by p53 transcription-dependent and independent pathways. J Biol Chem 2004; 279: 39431-7.

22. Burger H, Foekens JA, Look MP, Meijer-van Gelder ME, Klijn JG, Wiemer EA, Stoter G, Nooter K. RNA expression of breast cancer resistance protein, lung resistance-related protein, multidrug resistanceassociated proteins 1 and 2, and multidrug resistance gene 1 in breast cancer: correlation with chemotherapeutic response. Clin Cancer Res 2003; 9: 827-36.

23. Griffin D, Wittmann S, Guo F, Nimmanapalli R, Bali P, Wang HG, Bhalla K. Molecular determinants of epothilone B derivative (BMS 247550) and Apo-2L/TRAIL-induced apoptosis of human ovarian cancer cells. Gynecol Oncol 2003; 89: 37-47.

24. Khawaja NR, Carré M, Kovacic H, Estève MA, Braguer D. Patupilone-induced apoptosis is mediated by mitochondrial reactive oxy gen species through Bim relocalization to mitochondria. Mol Pharmacol 2008; 74: 1072-83.
25. Grosicki S, Grosicka A. Hołowiecki J. Kliniczne znaczenie angiogenezy i czynników ją modyfikujących w onkohematologii. Wiadomości Lekarskie 2007; 1-2: 39-46.

26. Bijman MN, van Nieuw Amerongen GP, Laurens N, van Hinsbergh VW, Boven E. Microtubule-targeting agents inhibit angiogenesis at subtoxic concentrations, a process associated with inhibition of Rac1 and Cdc42 activity and changes in the endothelial cytoskeleton. Mol Cancer Ther 2006; 5: 2348-57.

27. Chiorazzi A, Nicolini G, Canta A, et. al. Experimental epothilone B neurotoxicity: results of in vitro and in vivo studies. Neurobiol Dis 2009; 35: 270-7.

28. Quick QA. Epothilone B induces glioblastoma cell death via survivin down-regulation. Exp Oncol 2008; 30: 195-201.

29. Moreno-Aspitia A, Perez EA. Anthracycline- and/or taxane-resistant breast cancer: results of a literature review to determine the clinical challenges and current treatment trends. Clin Ther 2009; 31: 1619-40.

30. Sharom F.J. ABC multidrug transporters: structure, function and role in chemoresistance. Pharmacogenomics 2008; 9: 105-27.

31. Bergstralh DT, Taxman DJ, Chou TC, Danishefsky SJ, Ting JP. A comparison of signaling activities induced by Taxol and desoxyepothilone B. J Chemother 2004; 16: 563-76.

32. Lee FY, Covello KL, Castaneda S, Hawken DR, Kan D, Lewin A, Wen ML, Ryseck RP, et. al. Synergistic antitumor activity of ixabepilone (BMS-247550) plus bevacizumab in multiple in vivo tumor models. Clin Cancer Res 2008; 14: 8123-31.

33. Lee FY, Borzilleri R, Fairchild CR, Kamath A, Smykla R, Kramer R, Vite $\mathrm{G}$. Preclinical discovery of ixabepilone, a highly active antineoplastic agent. Cancer Chemother Pharmacol 2008; 63: 157-66.

34. Hofstetter B, Vuong V, Broggini-Tenzer A, et. al. Patupilone acts as radiosensitizing agent in multidrug-resistant cancer cells in vitro and in vivo. Clin Cancer Res 2005; 11: 1588-96.

35. Mani S, Huang H, Sundarababu S, Liu W, Kalpana G, Smith AB, Horwitz SB. Activation of the steroid and xenobiotic receptor (human pregnane $X$ receptor) by nontaxane microtubule-stabilizing agents. Clin Cancer Res 2005; 11: 6359-69.

36. Hopper-Borge E, Xu X, Shen T, Shi Z, Chen Z, Kruh GD. Human multidrug resistance protein 7 (ABCC10) is a resistance factor for nucleoside analogues and epothilone B. Cancer Res 2009; 69: 178-84.

37. Brunden KR, Trojanowski JQ, Lee VM. Advances in tau-focused drug discovery for Alzheimer's disease and related tauopathies. Nat Rev Drug Discov 2009; 8: 783-93.

38. Wittmann S, Bali P, Donapaty S, et. al. Flavopiridol down-regulates antiapoptotic proteins and sensitizes human breast cancer cells to epothilone B-induced apoptosis. Cancer Res 2003; 63: 93-9.

39. Pfeiffer B, Hauenstein K, Merz P, Gertsch J, Altmann KH. Synthesis and SAR of C12-C13-oxazoline derivatives of epothilone A. Bioorg Med Chem Lett 2009; 19: 3760-3.

40. Wang J, Zhang H, Ying L, Wang C, Jiang N, Zhou Y, Wang H, Bai H. Five new epothilone metabolites from Sorangium cellulosum strain So0157-2. J Antibiot 2009; 62: 483-7.

\section{Adres do korespondencji}

\section{dr Aneta Rogalska}

Katedra Termobiologii

Instytut Biofizyki

Uniwersytet Łódzki

ul. Banacha 12/16

90-237 Łódź

tel. +48 4263544 81, faks +48 426354473

e-mail: zychan@biol.uni.lodz.pl 